Concept Paper

\title{
Where Is the Money? The Intersectionality of the Spirit World and the Acquisition of Wealth
}

\section{Suleman Lazarus}

School of Humanities and Social Sciences, University of Greenwich, Park Row, London SE10 9LS, UK; suleman.lazarus@gmail.com

Received: 20 January 2019; Accepted: 22 February 2019; Published: 27 February 2019

\begin{abstract}
This article is a theoretical treatment of the ways in which local worldviews on wealth acquisition give rise to contemporary manifestations of spirituality in cyberspace. It unpacks spiritual (occult) economies and wealth generation through a historical perspective. The article 'devil advocates' the 'sainthood' of claimed law-abiding citizens, by highlighting that the line dividing them and the Nigerian cybercriminals (Yahoo-Boys) is blurred with regards to the use of magical means for material ends. By doing so, the article also illustrates that the intersectionality of the spirit world and the acquisition of wealth (crime or otherwise) is connected with local epistemologies and worldviews, and its contemporaneity has social security benefits. Therefore, the view that the contemporary manifestations of spirituality in cyberspace signify a 'new-danger' and an ever-increasing outrage in Nigerian society is misplaced. I conclude that if people believe all aspects of life are reflective of the spiritual world and determined by it, the spiritual realm, by implication, is the base of society, upon which sits the superstructure comprised of all aspects of life, especially wealth. Inferentially, this conceptual position that the spirit world is the base of society is an inversion of Orthodox Marxist's theory of economic determinism.
\end{abstract}

Keywords: sociology of religion; spiritual and magical powers; economic anthropology; gospel of prosperity; Mami Wata or Olokun; digital spiritualization; spiritual manipulation of victims; Nigerian cybercriminals and scams; occult economy; Yahoo Boys and money rituals

\section{Introduction}

The delinquent may not stand as an alien in the body of society but may represent a disturbing reflection or a caricature instead (Matza and Sykes 1961, p. 717).

\section{Money Doublers and Money Doubling}

Spiritual and magical powers, despite the fact that the dominant culture ignores and even denies their reality and contemporaneity, persist and continue to emerge in modern societies (Bever and Styers 2018). While it is of utmost importance to advance our understanding of the spiritual aspects of digital crimes (Melvin and Ayotunde 2010), the spiritual dimension of these crimes is under-theorized. This current endeavor is prompted by the need to urge cyber-fraud researchers to look beyond normal "scientific evidence" and consider the traces of "spiritual manipulations of victims" for material gains that are all too often ignored in "normal social science". A better understanding of this phenomenon lies in our capacity to unconditionally value all insights across the global South and global North (Cross 2018; Lazarus 2018). Indeed, crimes committed on the Internet constitute global issues, with 
global consequences (Kirillova et al. 2017), having brought, for example, Nigerian ${ }^{1}$ cybercriminals to the attention of the international community (Trend Micro and INTERPOL 2017). This article is broadly based on the premise that Nigerian cybercriminals who use magical/spiritual powers to defraud victims may not be "alien" to the body of society, to use Matza and Sykes's (1961, p. 717) term, but may represent a disturbing reflection or a caricature instead. The word "alien" here means "foreign", i.e., the characteristics of Nigerian society that are not its own. The article, therefore, sets out to trace the roots of contemporary manifestations of spirituality in a Nigerian context.

In order to achieve this, stepping backwards is enlightening. The contemporary manifestation of spirituality in cyberspace has to be analyzed with history in mind, to understand the past that created it. In the 1940s, before the digitalization of social life, many colonial head teachers observed that a group of Nigerian schoolboys (money doublers) were diabolic manipulators in trickery and scams (US Consulate 1949). These "money doublers" (Wayo-Boys) closely collaborated with indigenous spiritual knowers, such as herbalists or "native doctors" (Igwe 2007). While these "money doublers or Wayo-Boys" were implicated in defrauding many victims in Western societies with scam letters and magical amulets (Nkoh 1963), "money doubling" has always been associated with mystical powers in this context (Ellis 2016). This article, therefore, explores the importance of mystical and spiritual powers in wealth accumulation through the lens of cyber-spiritualism. For Tade (2013), "cyber-spiritualism" is the use of spiritual powers to defraud victims in cyberspace. Analogously, the defrauding of victims for monetary benefits is the most significant theme in the analysis of Nigerian cybercriminals and the "419-fraud" thesis (Ibrahim 2016a, 2016b). While many types of cyber-frauds are associated with the broader canon (Button and Cross 2017; Goutam and Verma 2015), the most widely known feature of all of them is 'deception' (Goutam and Verma 2015). The Nigerian cybercriminals, however, are predominantly known for Advance Fee Fraud (Dobovšek et al. 2013) which criminals themselves refer to as a 'game' (Lazarus 2018). Advance Fee Fraud or "419-fraud" is a 'game' for cybercriminals possibly because it embodies not only 'deception' but also includes a range of other characteristics. Such features include the manipulation of victims, the blaming of victims for their predicaments and the "dehumanization of victims" (Lazarus 2018, p. 70). Because Advance Fee Fraud (AFF) encompasses these multiple characteristics, the perpetrator-victim relationship and communication are paramount in the 'game'. Rich's (2018) comprehensive analysis of the Nigerian fraudulent emails, for example, elaborated that victims are commonly deceived into advancing relatively small sums of money in the hope of realising a much larger gain. The online versions of AFF are locally known as 'yahoo-yahoo ${ }^{3 \prime}$ (Akanle et al. 2016). The perpetrators of yahoo-yahoo were hence commonly known as "Yahoo-Boys" (Ogwezzy 2012). The term Yahoo-Boys not only signifies that the perpetrators of the infamous yahoo-yahoo are predominantly male (Cross 2018; Lazarus 2018), but also indicates that they are young. Other empirical studies support the youthhood ${ }^{4}$ of Yahoo-Boys as well (e.g., Aransiola and Asindemade 2011; Lazarus and Okolorie 2019).

In what ways are the actions of youths who tap spiritual resources for online gain a reflection of local epistemologies and worldviews in Nigeria? Are these actions alien in the body of Nigerian society? In attempting to answer these questions, this article will deconstruct the prevailing meaning of cyber-spiritualism in order to stimulate interdisciplinary dialogue. It will do so by weaving together published documents from across a number of disciplinary boundaries (West African poetry,

1 However, critical examinations have pointed out that the statistics the FBI relied upon to inform the currency of cybercrime perpetrators across nations, even when they represent the underlying reality, are socially and selectively constructed, and cannot (or should not) directly speak for themselves (Ibrahim 2016a, pp. 50-52).

2 The term " 419 " is historically derived from section 419 of the Nigerian Criminal Code which deals with multiple variations of frauds. Nowadays, " 419 " is 'loosely' used in everyday parlance as a simple antonym for cheating, falsification and fraudulent representation of facts.

3 The term 'yahoo-yahoo' originated from the dominance of Yahoo emails, apps and instant messaging in perpetrator-victim communications.

4 However, in the public discourse, people above 30 years of age are commonly and culturally seen as "youths"; the meaning of "youths" in Nigeria must be read in terms of the definitions they carry in a Nigerian context. 
religious studies, anthropology, sociology, and cultural criminology), to unpack the ways in which local epistemologies and worldviews on wealth acquisition give rise to contemporary manifestations of spirituality in cyberspace. While the inclusion of West African poetry, in particular, may seem strange to some modern sociologists, the sociological eye, as Longo (2015) suggested, can be sharpened by our engagement with literary sources. The deployment of these strategies is prompted by two central motives: (1) to underline that contextual realities on the ground should be taken seriously, beyond their particular geographical and disciplinary contexts; and (2) to underscore that the contextual and cultural realities should inform policymaking in the real world of a spiritually embedded economy.

\section{Defining "Digital Spiritualization"}

One of these realities is that many Nigerians, like the people before them, believe that the spirit world is the true source of material wealth (Akanle and Adejare 2018; Ellis 2016; Rosen 1989). In particular, many Nigerians believe that no one can succeed in his or her career, whether in crime or legitimate professions, without securing divine blessings, first and foremost, from spiritual beings (Ellis 2016; Rosen 1989). 'There are certain events in life that hard work or physical strength cannot achieve except one understands and possess some spiritual powers ${ }^{5 \prime}$ Notably, some qualitative studies have indicated that the Nigerian cybercriminals use magical powers to defraud victims all over the world (Melvin and Ayotunde 2010; Ibrahim 2016b). While some of these studies have implicitly ${ }^{6}$ observed the spiritual dimension of cyber-fraud (Aransiola and Asindemade 2011; Ajirola 2015; Ibrahim 2016b; Lazarus and Okolorie 2019), others have explicitly examined the same phenomenon (Melvin and Ayotunde 2010; Tade 2013). In recent years, what is remarkable is that most of these victims are mainly swindled in the context of "love" and "friendship" (Trend Micro and INTERPOL 2017). While some researchers hypothesized that the people who are most susceptible to the romance scam are those who describe themselves as seeking out perfect partners or "true" love (i.e., online profiles) (Whitty et al. 2017), this conjecture did not consider the role of charms and magic in romance-scam victimization. Many cybercriminals (Yahoo-Boys) control their "clients" (victims) with various spiritual means, known locally as "African Jazz" (Ajirola 2015; Information Nigeria 2017). Such spiritual means include, for example, putting spells on victims' photographs in shrines and communicating with them via the telephone (Information Nigeria 2017) through "words-of-power" (Peavy 2016), locally known as "do-as-I-say" (Ajirola 2015). The do-as-I-say spell or words-of-power include the use of verbal postulations to unlock cosmic forces that can make the spiritual manifest itself in the physical realm (Peavy 2016). In this way, spells can be invoked or undone by words-of-power or oratory postulations, depending on the invokers' intentions. For example, words-of-power could be invoked to enhance or inhibit a person's examination performance (educational-spiritualism), make a person fall in or out of love (love-spiritualism) or help a person recover from illness or become ill (health-spiritualism). Concerning the role of charms and magic in online scam victimization, the narratives of frontline law enforcement officers are revealing. According to Lazarus and Okolorie's (2019, p. 24) study which interviewed 40 Economic and Financial Crimes Commission agents, one of the ritualized practices used by some Nigerian cybercriminals to manipulate their victims is:

to put a victim's picture under the laptop [that is] after the spiritualist (native doctor) might have "worked on" the picture (cast a spell on it possibly in his/her shrine). It is then necessary and sufficient for fraudsters to simply place the photograph under the computer while chatting/messaging the victims of fraud. Also, in the words of one respondent, "fraudsters also talk to the [victims'] pictures repeatedly" which represent the words-of-power ("do as I say" rhetoric).

5 A direct quote from one of Melvin and Ayotunde (2010, p. 369) participants.

6 Explicit and implicit: for example, Ibrahim (2016b) interviewed 17 parents regarding children's vulnerability to involvement in cybercrime (implicit), whereas Tade (2013) interviewed 10 Yahoo-Boys on the spiritual dimension of cybercrime (explicit). However, while both studies relied on different groups of Nigerians as participants, i.e., parents and Yahoo-Boys, they agreed on the significance of spiritual and magical powers in the discussion of cyber-frauds that emanate from Nigeria. 
Yahoo-Boys commonly not only use spiritual means to increase the economic benefit of their fraudulent activities, but also use them as "spiritual insurance" so that no harm may befall them while carrying out their criminal activities (e.g., Adebayo 2013; Lazarus and Okolorie 2019). Based on the preceding remarks, I will henceforth deploy a more critical examination of the existing literature on spirituality in cyberspace, or cyber-spiritualism. While there is a dearth of empirical studies on this topic, my quarrel with the current definition of cyber-spiritualism (Tade 2013) or "spirituality in cyberspace" (Melvin and Ayotunde 2010) is based on three central reasons. In particular, while I build on Tade's (2013, p. 702) and Melvin and Ayotunde's (2010, p. 374) work on spirituality in cyberspace, I disagree with them in three related ways: (1) I question the implicit polarization of the real world and the virtual world, which ignores that cyber-spiritualism has emerged from a well-established origin; (2) I disagree with the assertion that cyber-spiritualism has a singular meaning; and (3) I oppose the negativization of spirituality in the virtual world.

First, Melvin and Ayotunde (2010, p. 364) drew from the Yoruba ${ }^{7}$ cultural cosmos (Nigeria) and explained that 'spirituality has been a crucial factor in the activities of offenders involved in both organized and non-organized crimes' in the virtual world. Accordingly, cybercriminals (Yahoo-Boys) who defraud their victims using supernatural powers are called "Yahoo-Boys plus" (Melvin and Ayotunde 2010). Building on Melvin and Ayotunde's (2010) work, Tade (2013, p. 690) defined cyber-spiritualism as

a cybercrime strategy which blends spiritual elements with internet surfing to enhance victimisation rates on the web. Cyber spiritualism involves the procurement and use of mystical, spiritual, and supernatural powers by yahoo boys to cast a spell on their victims. Through this method, victims become hypnotised and, without objection, offer their treasures (products and money) to the fraudsters.

These lines capture how the author interpreted the meaning of cyber-spiritualism. While the above meaning of cyber-spiritualism does not deal with offline fraud practices, it sheds light on how cybercriminals, through their inventiveness, deployed offline beliefs and practices on the Internet. It is this inventiveness that the above author conceives as alien and, by the same token, the term cyber-spiritualism (this accusation is justified further down). As far as this article is concerned, offline practices predate online ones; the licit and illicit tapping of spiritual resources for wealth acquisition offline predates the use of this practice online, and clarifies the concept of cyber-spiritualism. By the same token, it agrees with the notion that the polarization of the real world and the virtual world obstructs the understanding of socially constructed cues offline, which are concurrently impactful in the digital realm (McGerty 2000; Jaishankar 2007; Powell et al. 2018). Many researchers have indeed highlighted the "life-offline" and "life-online" linkages ${ }^{8}$, but they have coined different phrases or joined different sets of words to express the same idea. For example" ${ }^{9}$, while for McGerty (2000, p. 895) "nobody lives only in cyberspace", for Morahan-Martin (2000, p. 689) "life online is a mere extension of life offline". While Jaishankar $(2007,2011)$ factored a crime element into the equation and called it "cyber criminology", Powell et al. $(2017,2018)$ on the one hand renamed Jaishankar's (2011) version as "digital criminology", they on the other hand elaborated on the notion that the "life-offline" and "life-online" are inseparable (e.g., McGerty 2000; Morahan-Martin 2000) and captured this notion as "digital society". While the preceding remarks may not represent the entirety of the above authors' contributions, they help to shed light on the pattern of the body of knowledge on which this current scholarly endeavor leans. Therefore, I argue that this contemporary phenomenon called cyber-spiritualism is, like history, the witness that testifies to the passing of time. ${ }^{10}$

7 'Yoruba' constitutes one of the main three ethnic groups in Nigeria (the other two are Hausa and Igbo).

8 The "life-online and life-online" connections are also reminiscent of Goffman's (Goffman [1959] 1990) notion of the "front-stage" and "back-stage" interactions.

9 This is by no means an exhaustive list of relevant authors on this topic (life-offline and life-online connections) but it gives an indication of the layers of contributions prior to this current endeavor.

10 Paraphrased from Marcus Cicero's famous words, "history is the witness that testifies to the passing of time". 
Second, based on the above remarks, it is conceivable that the historical backdrop to spirituality in cyberspace is indeed the licit or illicit occult economy in society (Comaroff and Comaroff 1999; Jansen 2011). For this article, the occult economy can be understood as the deployment, real or imagined, of magical means for material ends (Comaroff and Comaroff 1999; Jansen 2011; Steinmüller 2011). Accordingly, this inquiry will draw upon indigenous epistemologies and worldviews to challenge the simplistic rendering of cyber-spiritualism in Nigerian society as alien because of the following reasons: (1) cyber-spiritualism has emerged from a well-established origin; (2) spirituality in cyberspace is a reflection of the past that created it. By the same token, cyber-spiritualism has a dual meaning, since it reflects both the "licit" and the "illicit" components of the occult economy from which it has emerged (e.g., spiritually blessing or cursing a person). Cyber-spiritualism, therefore, has, like the occult economy, a dual meaning or two dimensions: licit and illicit. Thus, this current endeavor defines digital spiritualization or cyber-spiritualism as the use of magical and spiritual powers in cyberspace for functional purposes (e.g., online job applications or online examinations) or dysfunctional purposes (e.g., online scamming or online stalking), depending on subscribers' intentions and the circumstances they address. Moreover, cyber-spiritualism concurrently manifests in the physical space. Arguably, Melvin and Ayotunde (2010, p. 374) and Tade (2013, p. 702) err in conceiving cyber-spiritualism as a singularity, and this misconception has implications, such as the negativization of spirituality in cyberspace.

Third, by assuming that cyber-spiritualism has a singular meaning, the above authors fundamentally constructed it as a troubling phenomenon that needs to be addressed or solved (Best 2008, pp. 14-15). The negativization of spirituality in cybercrime is another basis of my quarrel with the prevailing conceptualization of cyber-spiritualism. For example, Tade (2013, p. 702) particularly claimed that "cyber spiritualism portends danger for a developing country like Nigeria. It leads to image battering which impedes development. A way out of this social ill is a genuine restructuring of the social values of Nigerian society". These authors represented cyber-spiritualism as a phenomenon that symbolizes a new societal problem, that "portends danger" (Tade 2013, p. 702) and "calls for concern" (Melvin and Ayotunde 2010, p. 374). The current endeavor does not intend to justify the illicit occult economy in cyberspace. However, it points out that the manifestation of spirituality in cyberspace is a reflection of a broader and widely accepted indigenous spiritual epistemology and worldview in Nigeria (which is contextualized further down). The claim-makers here (Melvin and Ayotunde 2010; Tade 2013) constructed cyber-spiritualism as a phenomenon that should be recognized as troubling or as a social problem (Best 2008; Gabe and Bury 1988). The negativization of spirituality in cybercrime dislocates it from the well-established indigenous worldview from which cyber-spiritualism emerged. Digital spiritualization or cyber-spiritualism is a reflection of the past that created it. By implication, the negativization of cyber-spirituality echoes chronocentrism. Chronocentrism is a "misconception that one's times are paramount, [while] other periods pale in comparison" (Fowles 1977 , p. 1). It is referring to the slighting of the past's historical importance, while exaggerating the historical significance (positive or negative) of the present (Rock 2005). Hence, in an attempt to further justify my disagreement with Tade's (2013, pp. 690, 702) and Melvin and Ayotunde's (2010, p. 374) positions, I will explore the occult economy in a variety of different manifestations, namely: (1) The traditional African spiritual system; (2) the Olokun deity; (3) the Gospel of Prosperity; and (4) the villagization of the modern public sphere, in order to nuance the intersectionality of the spirit world and the acquisition of wealth.

\section{Different Manifestations of the Occult Economy}

\subsection{Traditional African Spiritual System}

The contemporary manifestation, i.e., cyber-spiritualism, serves as an entry point to the intersectionality of the spirit world and the acquisition of wealth in a Nigerian context. Since "a social phenomenon cannot ultimately be understood apart from the cultural context in which it occurs" 
(Beirne 1983, p. 373), it is reasonable to consider how it may be a reflection of a broader Traditional African Spiritual System (TASS). The TASS constitutes both the "good" and the "bad" elements, depending on subscribers' intentionality as well as the circumstances they are addressing (Peek 2016; Smalls 2015). In the TASS, all aspects of life, wealth, health, death, and happiness have their roots in the spiritual realm, the authorities therein consisting of a Supreme Being, lesser divinities, ancestors, and spirits (Magezi and Magezi 2017; Peavy 2016). If people have a good relationship with the principal figures in the spirit world, they will be rewarded with wealth, health, happiness, and protection (Smalls 2015; Washington 2012). Conversely, a breakdown of a harmonious relationship between the spirit world and the physical one has adverse consequences for humans (e.g., sickness, barrenness, death) (Peavy 2016; Smalls 2015).

Since all aspects of life are reflective of the spiritual world and determined by it, the spiritual world is, therefore, the base of society, upon which sits the superstructure, comprised of all aspects of life such as material wealth. The conception that the spirit world determines the material conditions is an inversion of Orthodox Marxist's theory of economic determinism. For Marx and Engel's (Marx and Engel 1967) theory of economic determinism, the economy is the base of society that shapes all its institutions such as family, education, government, religion and the media. Simply put, while Marxist's theory positions the economy as the base of society, it situates religion as a part of the superstructure. Conversely, I argue in this article that the spirit world is the base of society, for believers, in a Nigerian context. Nonetheless, for symbolic interactionists, the meanings that things and social objects (persons) have for people form the basis of their actions (Blumer 1969a, 1969a). Equally, a good relationship or a breakdown of a harmonious relationship between the spirit world and the physical one is associated with the broader socio-moral order and indigenous penal thoughts (Assimeng 1986). While indigenous penal thoughts are rooted in the spiritual realm, the centrality of spiritual beings in people's lives is apparent in Assimeng's (1986, p. 49) and Tankebe's (2008, p. 69) notion of "escapelessness" (an aspect of TASS):

Escapelessness meant that the ancestral spirits were thought to be all-knowing; no violation of the norms of society escaped their surveillance, and no offender did. The "severity" of sanctions was used to deter the rest of society; the ancestral spirits were thereby upholders of the socio-moral order.

Hence, some West African literary scholars (Brew 1975; Clark 1975; Okri 1991) reminded us that people are their ancestors; they follow their footsteps and rarely live in "new times". Since spiritual beings were the upholders of law and order, one might be inclined to suggest that the concept of escapelessness might retain its efficacy online, as it does offline in contemporary Nigeria and elsewhere. Equally, given that the meanings that things and social objects (persons) have for people are the basis of their actions (as mentioned earlier), the contemporaneity of escapelessness in the virtual world highlights the value of the interactionist perspective in the area of cybercrime and cybersecurity. Relatedly, it is therefore common for families to go beyond life's physical challenges to assess their spiritual etiology, since every existential problem is rooted in the spiritual realm according to TASS (Peavy 2016; Sogolo 1991; Washington 2012). Essentially, the manifestation of life's problems necessitates inquiries into the spiritual world for remedies. It also provides guidance on relationship maintenance between the two worlds (Peavy 2016; Peek 2016). For example, a person may sacrifice a goat to ancestors for relationship maintenance. It is believed that when the goat is killed, the vital energy that was the goat is released. In turn, the released energy can then be captured and reused in TASS for "good" purposes, such as asking supernatural authorities for healing, prosperity, and other worthy purposes, or for "bad" purposes, such asking them to curse or aggravate people (Smalls 2015).

Cyber-spiritualism, therefore, is "old wine in a new bottle" that connects with the concept of escapelessness in social surveillance. If an individual believes that ancestral spirits are omnipresent and omnipotent, they are omnipresent and omnipotent in their consequences. In fact, legitimacy and conformity to social rules are central to self-regulation (Tyler 1990; Weber [1946] 1992). What is remarkable here is the legitimacy and meaning that spiritual powers hold for a vast, generalizable body of Nigerian society in their unquestioned conformity to rules that are believed to derive from 
ancestral spirits and powers. They do not question the legitimacy of the ancestral spirits and gods; they accept their existence, as they perceive themselves as beneficiaries of their rules, all embedded in the concept of escapelessness. For example, most Nigerians would not hesitate to adhere to warning signs associated with "spiritual powers", as shown in Figure 1a,b, because they believe that no offenders can escape their surveillance. The concept of escapelessness could help to facilitate cybersecurity in West Africa, as has been demonstrated in other aspects of security in West Africa from the distant past to the present.

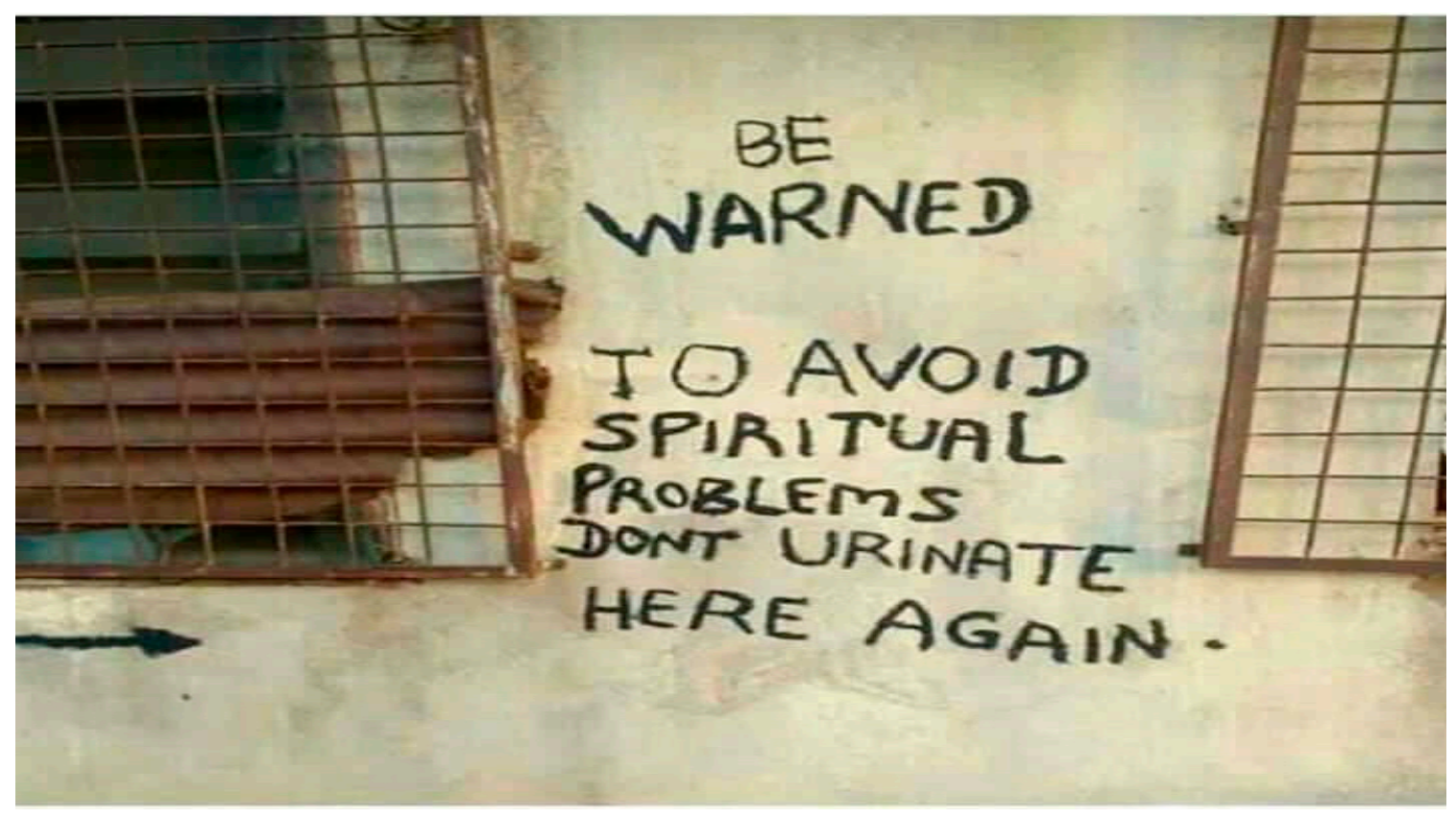

(a)

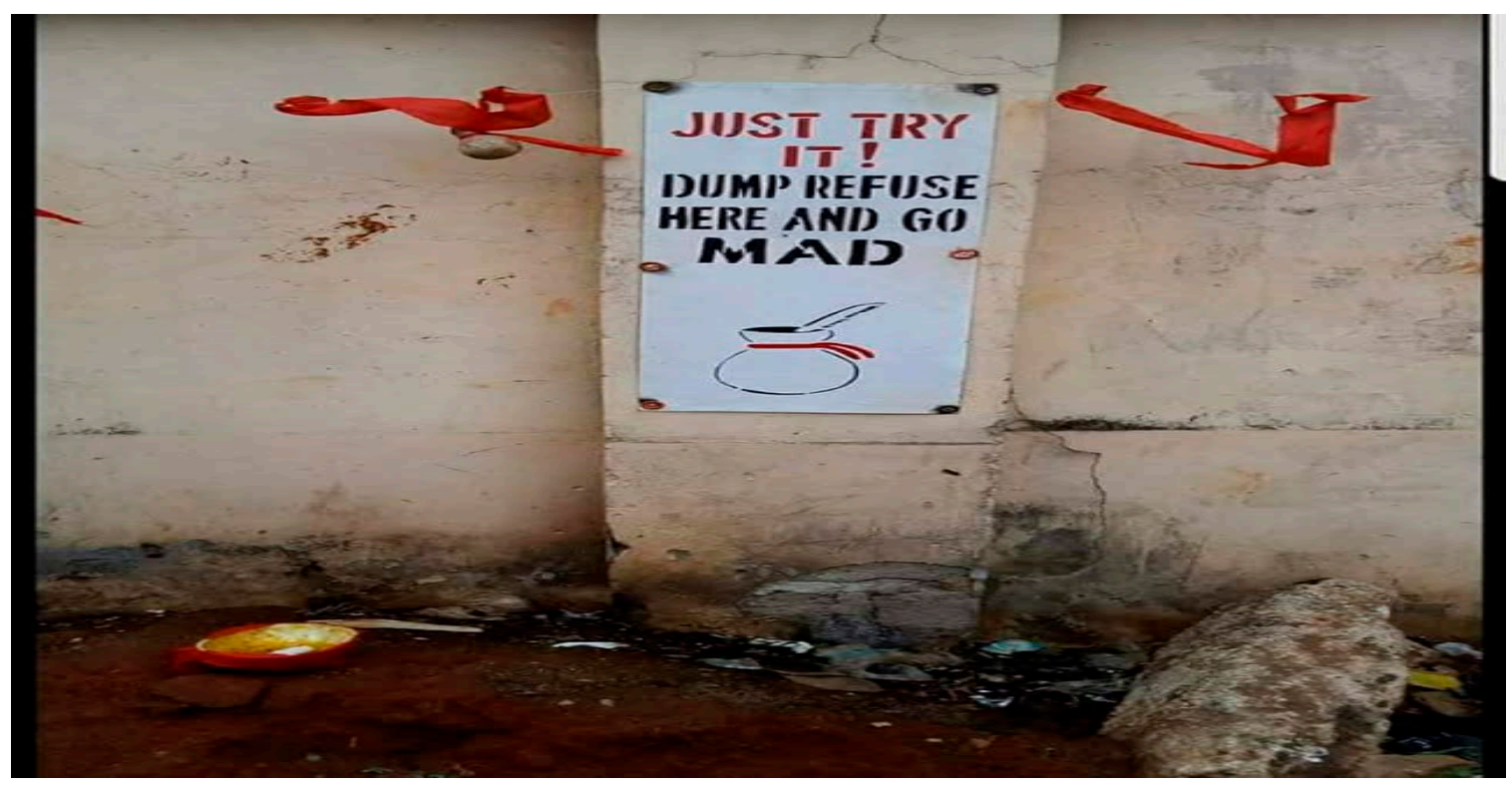

(b)

Figure 1. (a) Reflections of Escapelessness, (b) Reflections of Escapelessness.

Based on the efficacy of spiritual powers as security tools in Nigeria, as shown in Figure 1a,b, I disagree with the mainstream security-principles that repressive technologies (e.g., mass incarcerations) would succeed in Africa, including in Nigeria (see also Cohen 1988; Agozino 2017). 
This current article, therefore, advocates for agents of the overall cybersecurity ecosystem to take on board the importance of spirituality in the lives of digital-age Nigerians. While spiritual beings are the true givers of wealth (Ellis 2016), no offender or violation of social norms escapes their surveillance (Tankebe 2008). Because of this, it is conceivable in Nigeria that a central prerequisite for analyzing material welfare is not only an understanding of a person or people's spiritual welfare (Ellis 2016; Kalu 1977), but also an understanding of real-life social security implications (e.g., escapelessness). Having used the TASS to illustrate that cyber-spiritualism has emerged from a well-established indigenous spiritual worldview, I will henceforth draw upon the concept of the Olokun deity.

\subsection{Olokun}

\section{So drunken, like ancient walls}

We crumble in heaps at your feet;

And as the good maid of the sea,

Full of rich bounties for men,

You lift us all beggars to your breast-Clark (1975, p. 44)

Our engagement with literary sources can sharpen the sociological eye (Longo 2015). As depicted in Clark's (1975) poem above, decoding the name "Olokun", popularly known in the global West African diaspora as "Mami Wata" (mother of water), is a critical entry point for analyzing spiritual welfare as material welfare in a Nigerian context (Rosen 1989). In the ancient mythology of the Benin kingdom, ${ }^{11}$ Olokun is considered the giver of material wealth (Peavy 2016). Olokun is a critical entry point for understanding the symbolic meaning of the spiritual realm as a real source of economic power in Nigerian communities. Mami Wata is the water spirit, culturally and popularly believed to possess immeasurable riches in its kingdom beneath the sea (e.g., in Yoruba, Igbo, and Edo culture in present-day Nigeria) (Rosen 1989; Peavy 2016). Where is the money? If people believe Mami Wata's kingdom is where the real ${ }^{12}$ money is, Mami Wata's kingdom is real in its consequences (Thomas and Thomas 1928). Accordingly, worshippers commonly offer sacrifices to the deity of money for blessings believed to exist in abundance beneath the sea. Therefore, worshippers act based on the meanings Olokun has for them. The reciprocal exchanges between families and their "imagined others" in the spirit world are critical to the relationship between them (Falola 1995; Guyer 2004). The mutual exchanges implicitly expressed, such as when praying, or explicitly demonstrated, such as when tithing, ensure the coming and going of souls and things that are all intermingled with one another (Droz and Gez 2015). Notably, the spirit world and the realities of financial success were strongly linked in the social communities that became known as Nigeria ${ }^{13}$ (Kalu 1977). For symbolic interactionists, while meanings are the basis of human actions, these are reproduced through interactions with beings (e.g., the water spirit and members of human society) (Blumer 1969a). In a Nigerian context, it is conceivable that these meanings are derived from socio-spiritual interactions.

The significance of Olokun in Nigerian culture reinforces the notion that the spirit world is the real source of wealth for adherents who often offer sacrifices. These sacrifices or customary "handshakes" with Olokun or Mami Wata have reciprocal effects. While the givers may receive earthly wealth, they are indebted to Olokun in terms of obedience and further sacrifices (Rosen 1989; Peavy 2016). "Gifts to humans and the gods serve the purpose of buying peace between them both" (Mauss 1925, p. 21). For this article, the meaning of "wealth" is not merely about material wealth (money), but also

11 Contemporary Nigerian society has sprouted from the ruins of three ancient West African kingdoms: the Benin Kingdom, the Bornu Empire, and the Songhai Empire (Ibrahim 2016a).

12 The encounter of a famous Nigerian singer, Sir Victor Uwaifo, with Mami Wata is recounted here: http:/ / www.informationng. com/2015/09/meet-sir-victor-uwaifo-the-nigerian-musician-who-saw-a-real-mermaid-narrates-experience.html.

13 On 1 January 1914, His Majesty the King of Great Britain amalgamated the Northern and Southern British Protectorates into the colony of Nigeria. Nigeria remained a British colony until 1960 (Lazarus et al. 2017). 
encompasses other aspects of life such as fertility, children, good health, and happiness (e.g., Ellis 2016), which helps explain indigenous epistemologies of prosperity. In particular, wealth could come to adherents in the form of fertility and a baby boom in the extended family. Large numbers of children are culturally seen as an essential aspect of wealth. Children are believed to be gifts of the gods, and the significance of children is evident in some Nigerian names ${ }^{14}$ (Amadi et al. 2017). By the same token, the contemporaneity of the preceding statements is evident in these Nigerian names ${ }^{15}$ (Amadi et al. 2017), which concomitantly explain indigenous epistemologies of prosperity (e.g., in the Yoruba, Igbo, and Edo languages). Nigeria has over five hundred local languages (Lazarus 2018), but these multi-ethnic variations have a historical bond in the spiritual significance of children's names (Amadi et al. 2017).

The spiritual significance of some Nigerian names highlights the notion of wealth that people have. To have large families (wives and children) is an excellent source of wealth. Wealth is strongly associated with mystical and spiritual powers. Consistent with the indigenous epistemologies of prosperity, people who are wealthy were and are presently thought to have special blessings from the invisible world (Falola 1995; Peavy 2016). Large numbers of children manifest by implication in an abundance of material wealth (Peavy 2016). Large numbers of servants and slaves are also symbols of wealth and favor from gods such as Olokun (Rosen 1989; Peek 2016). For example, in the pre-colonial era, people who accumulated more wealth than their neighbors were thought to have received special favors from the spirit world (Ellis 2016). Consequently, a farmer who has more land and laborers (e.g., children, wives, slaves, servants) would prosper more than his peers-in terms of land and people (Falola 1995). In fact, as Peavy (2016) explained, some Nigerians believed that no one ever lives without knowing the arch spirit of wealth called Olokun or Mami Wata, a real symbol of "wealth".

By implication, for believers, no one can buy or sell anything without having to touch and know money, Olokun. To have a good relationship with the spirit world guarantees material rewards (children, slaves, and servants); which is an inversion of Orthodox Marxist's theory of economic determinism as previously mentioned. For instance, a slave or a servant represents a store of value, and wealth-in-people could easily translate into wealth-in-money (Ellis 2016; Guyer 2004). Every good relationship requires maintenance. Having strong allies and networks of people were useful assets in the accumulation of wealth, for example when paying (bride prices) for wives or selling/buying slaves for a different purpose, such as valuable items to be sacrificed to the spirit world (Guyer 2004). The preceding comments illuminate how the invisible world becomes central to the acquisition of slaves in pre-colonial Nigeria, and align with the idea that the spirit world is indeed the actual source of wealth. For example, until the late 1950s, the Aro shrine ${ }^{16}$ (also known as the long-juju shrine) served as the theocratic administrative machinery (Ellis 2016; Shankland 1933). It also had the power to bless adherents and curse transgressors and their families (Shankland 1933). A fuller analysis of the contemporaneity shrines in modern Nigeria is given below.

A standard method of punishing the convicted-without extending the punishment to the transgressor's family members-was to sell the sentenced into slavery (if the transgressor's "kinsmen" were not able to pay a certain amount of money to the administrative system of the shrine) (Falola 1995). Once such a shrine ${ }^{17}$ has turned a person into a slave, it does not matter if the individual was sold or freed by his/her family; that person symbolizes a store of value one way or the other. Some

14 Such as (1) Oyagbemi in the Yoruba language, meaning "the goddess has rewarded me"; and Chukwuyem in Igbo language, meaning "Almighty God gave me (child)".

15 Such as (1) Omosigho in the Edo language, meaning "a child is more valuable than money"; (2) Efemena in the Isoko/Urhobo language, meaning "this one (child) is my wealth"; and (3) Nwakaego in the Igbo language, meaning "a child is greater than material wealth".

16 Whilst the Aro-shrine was geographically located in the Eastern Nigerian region, its spiritual effects extended to present-day Congo and Sierra Leone (Shankland 1933).

17 Also, similar to 'Trokosi' spiritual practice in Ghana (another West African country), where any adult who transgresses against the collective sentiment of the village social community submits a young girl from his/her family to the traditional Shrine Priest to labour and serve for 3-5 years in shrines as a way of atonement (Rush and Lazarus 2018). 
people believe in the long-juju shrine's power over life and death. By implication, the long-juju shrine is omnipotent in its judgments and consequences. It recalls Thomas and Thomas's (1928) idea that if people believe situations are real, they are real in their consequences. Relatedly, most ritual killings of victims (often slaves) were believed to increase the wealth of the person who offered the sacrifice of the victim to the invisible world, reinforcing the real source of wealth (Agozino 2017; Falola 1995; Kalu 1977). In every conceivable manner, the spirit world is no less significant today than in the Nigerian past. It is reasonable to suggest that the belief that the spirit world is the actual source of wealth is a link to the past and a bridge to our future. For example, the contemporaneity of ritual killings for money success is well documented in various discourses (Aghedo 2015; Agozino 2017; Igbinovia 1988).

In most cases in contemporary Nigeria, as Aghedo (2015, p. 140) explained, the perpetrators would kill the victims and take "vital parts of their bodies" for money rituals. Although the ritual killing of a human is inhuman and gruesome, its contemporaneity in Nigeria also reinforces the indigenous epistemologies about the use of magical powers to "get rich" (Aghedo 2015; Igbinovia 1988). While the use of human body parts for money rituals reflects the "dark side" of magical/spiritual exploitation, it is legally and publicly condemned in Nigerian society. In fact, the killing of a human for money rituals often results in public vigilante justice against the perpetrators, especially in the public discourse (Aghedo 2015). However, the condemnation of ritual killings does not undermine the idea that some Nigerians see spiritual welfare as material welfare (Agozino 2017). Equally, it is noteworthy that not every Nigerian subscribes to the power of the spiritual realm in dictating the outworking of the physical and social domains, be it "good or evil". One may be inclined to presume that most subscribers (e.g., to the Olokun deity) would be from Yorubaland or Benin, but this is only due to the prominence of depictions of these groups in the existing literature (Rosen 1989; Peavy 2016). There are no statistical data to support speculations regarding the features of those who tap religious resources for wealth accumulation. Even if such data exist, there is a danger of failing to capture indigenous spiritualities in all their complexity, beyond their physical-geographical context or ethnic groups that are represented or directly implicated in the literature.

A more critical issue is perhaps that subscribers must make a distinction between benevolent and malevolent spiritual agencies, good and evil intentionality. This article does not suggest that the cultural interpretation of the use of spiritualism for licit and illicit ends acts as one and the same. Equally, it does not intend to reify and justify a fraudulent act (yahoo-yahoo) that many Nigerians condemn themselves, not least in light of the use of magical/spiritual powers by some Yahoo-Boys to defraud victims all over the world. Many Nigerians, for instance, culturally view the use of spiritualism to seek licit favors and blessings such as fertility, promotion, healing, in a positive light. On the flip side, the same cannot be said concerning the use of such spiritualism to attain wealth through ritual killings. For example, according to recent trends in social media, many Nigerians condemned cybercriminals who steal women's panties, sometimes at gun $/$ knife points, for money rituals ${ }^{18}$ The financial realities of women's panties in Nigeria are reflective of a spiritually embedded economy and also reinforce that indeed, the spirit world is the real source of wealth. Nonetheless, the preceding remarks on the concept of the Olokun deity shed light on how cyber-spiritualism may have emerged-it could be seen as a reflection of the past that created it. Utilizing a historical perspective, I have used the concept of the Olokun deity to argue that the allure and reproduction of mystical/spiritual agency and its appropriation by cybercriminals (Yahoo-boys) in their virtual transactions reflect a well-established socio-spiritual script in the discourse on wealth accumulation in Nigeria. By implication, digital spiritualization is the intersectionality of the spirit world and the acquisition of wealth in cyberspace. I will henceforward draw on the concept of the "Gospel of Prosperity" (Adogame 2010; Heuser 2016; Kangwa 2016; Lausanne Theology Working Group 2010) to further contextualize this intersectionality.

18 Media sources such as, "Fear of 'Yahoo boys', ritualists forced female students in Delta state tertiary schools to stop wearing pants": https:/ / www.legit.ng/1211206-fear-yahoo-boys-ritualists-forced-female-students-delta-state-tertiary-schoolsstop-wearing-pants.html. 


\subsection{The Gospel of Prosperity}

Historically, the Nigerian religious landscape, representing West Africa, has metamorphosed from the debris of beliefs / practices in the pre-colonial era into a multiplicity of religious traditions (Adogame 2010; Adogame et al. 2012; Heuser 2016; Magezi and Magezi 2017). This multitude of religiosities includes the indigenous religions (embodying shrines) and the Abrahamic religions, i.e., various strands of Christianity and Islam (Kangwa 2016). I draw mainly upon African Christianity, due to the significance of the "Gospel of Prosperity" (Heuser 2016; Lausanne Theology Working Group 2010) in teasing out much of the innovative energy in prosperity-oriented faith in God. The Gospel of Prosperity involves the power of divination, offerings, tithing, and material-prosperity oriented "prayers" (Csordas 2009; Kangwa 2016). Symbolically, these interactions with the imagined others (e.g., offering, tithing, praying) merge the spirit world and the physical world (Heuser 2016). As Nigerian sociocultural relationships are codified and guaranteed via the spirit world (Washington 2012), loyalty and "tithing" are essential aspects of social relationships and Nigerian sociocultural identity, and serve to bind modern-day Nigerians and their "kinsmen" (Ellis 2016). In gift giving (e.g., offering and tithing), the honor of giver and recipient is reciprocally engaged (Mauss 1925). For Droz and Gez (2015), gift exchanges, offering, and tithing are a form of ritualized bonding between believers and God. The critical point here is that quest for wealth-oriented mystical manipulation, which is a reflection of TASS, is a specific aspect of multiple strands of African Christianity in contemporary Nigerian society (Amanze 2013; Magezi and Magezi 2017). One may say that culture is an interwoven set of beliefs and practices that define people's way of life. Unlike DNA, culture is not innate or embedded in the chromosomes, but like DNA, it is a reflection of ancestral faces ${ }^{19}$. African Christianity is not immune to local epistemologies of wealth acquisition (Amanze 2013). For Kangwa (2016), African churches, including Nigerian churches, embody a culture of continuity by reproducing an identifiable character and regaining a pneumatic and charismatic religiosity that existed in traditional African society with their prophetic energy.

The power of divination connection with occult economies is central to traditional African society (Jansen 2011; Kangwa 2016). The power of clairvoyance is the conveyor belt on which the present life situation is transported to the future, so that glimpses of the future can direct the current waves of present life events (Jansen 2011; Peek 1991). At the core of divinity lies the power of the word (Washington 2012), and the practices of the oracular words (words-of-power) are commonplace in Nigeria (Ellis 2016). To fully understand the concept of words-of-power, we must examine the intentionality that created it (benevolent or malevolent). Depending on the issues the concept of words-of-power is invoked to address, the use of words-of-power in itself is not an inherently immoral act. While the featuring or absence of prophecy and words-of-power in churches determines their growth, pastors who can prophesize and work miracles with oracular words-of-power undoubtedly would have more followers than their peers (Kangwa 2016). Indeed, words-of-power is a critical tool in the success or failure of the Gospel of Prosperity, which lies at the core of African Christianity. Where is the money? The spirit world is a true source of wealth in modern Nigerian churches (Akanle and Adejare 2018, p. 7) (and as emphasized elsewhere, by implication, cyber-spiritualism may not be an alien in the body of Nigerian society). Similarly, Kangwa (2016, p. 4) observed:

Material blessings (fertility and children, good health, secure shelter, plentiful harvests) are explained as signs of divine blessing. Conversely, the root of all problems is spiritual and, therefore, the solution must also be spiritual. If one cannot overcome by oneself the forces that hinder success, one has to look for assistance from those who have the power needed to summon or manipulate spiritual forces.

For example, there is an elaborate procedure for selecting a spouse, and it is not uncommon for families of spouses-to-be to ascertain that their family-in-law-to-be does not suffer from curses or

19 Paraphrased from James Small's sentence, during one of his public speeches on “Occult". 
illnesses such as leprosy, and/or is not noted for witchery/wizardry. In particular, such investigation of the affine is often done by exploiting the spirit world, to expose the future and the hidden history of their family-in-law-to-be (Amponsah et al. 2006). Also, Chinwoke Mbadinuju, the governor of Anambra state in Nigeria (1999-2003), ordered members of his cabinet to swear an oath of loyalty at an Okija-shrine ${ }^{20}$ to ensure the influx of his "assorted" gifts, and they did (Ellis 2016; Ujumadu 2015). There is no statistical data to estimate the numbers of law-abiding citizens who tap religious resources for wealth accumulation. However, it is not uncommon for claimed Christians who are in politics in Nigeria, from local councilors to presidential candidates, to exploit the spirit world via pastors and native doctors as a critical part of election preparation and career enhancement (Ellis 2016). There is no objective viewpoint to critique or compliment this as an "immoral" act (Becker [1974] 1967; Reiner 2016).

Besides, cyber-spiritualism has a dual meaning. Its "good" and "bad" components depend on subscribers' intentionality as well as the circumstances and life problems they are invoked to address. Like claimed law-abiding Nigerians, Yahoo-Boys, far from deviating, conform to the commonly held indigenous worldview. So, in "devil advocating" 21 the "sainthood" of claimed law-abiding citizens, the argument's critical point here is that the motivations informing spirituality in cyberspace (or in any form of the licit/illicit occult economy, for that matter) are based on local epistemologies and worldviews. For example, Lazarus's (2018) study on the representations ${ }^{22}$ of Yahoo-Boys in hip-hop music is revealing, because it demonstrated that the Yahoo-Boys' embodiment of spirituality is reminiscent of the Gospel of Prosperity. In this study (Lazarus 2018, p. 73):

a singer, Kelly Handsome, depicted Yahoo-Boys as follows, " . . Maga don pay/ Mugu don pay/shout hallelujah ... / ... hallelujah hallelujah owo ... / .. / . . hallelujah hallelujah ego ... / ... hallelujah, hallelujah kudi, kudi... /I don suffer, but I now don hammer, papa God don bless me, no one can change it ... / ...". (The gullible has paid, the senseless has remitted/shout hallelujah ... / ... hallelujah, hallelujah money ... / . . hallelujah, hallelujah money ... / . . /hallelujah, hallelujah money, money ... I have suffered a lot, but now I have hit the jackpot, Almighty God has blessed me, [and] no one can change it).

Considering the biblical allusion above (i.e., a reference to the Bible regarding prosperity as a critical element of religiosity), the line dividing cybercriminals and claimed law-abiding Nigerians is blurred. In other words, with regards to the use of spiritual and magical powers for wealth acquisition, the seeming distinction between cybercriminals and claimed law-abiding Nigerians is far from straightforward. The preceding remarks further suggest that cyber-spiritualism cannot ultimately be understood apart from the sociocultural context in which it occurs (because it has a history). Equally, the bottom line here is that material gain is a prime motivation for cyber-spiritualism on the one hand. On the other hand, the notion that the spirit world is the true source of wealth is an inversion of Orthodox Marxist's theory of economic determinism as previously mentioned. Having used the Gospel of Prosperity to contextualize cyber-spiritualism, I henceforth use the analysis of Kalu (2002) and his term "the villagization of the modern public sphere" to nuance the intersectionality of the spirit world and the acquisition of wealth.

20 Over 70 human bodies and skulls were discovered on the premises of the Okija-shrine in 2015 (covering about a decade).

21 Here, the phrase "devil advocating", means arguing against the 'righteousness' or 'sainthood' of a group (claimed law-abiding citizens) in order to uncover any misrepresentation of the evidence favouring them (e.g., concerning the use of magical/spiritual powers for wealth generation).

22 It is noteworthy that the representation of fraudsters by Nigerian singers predates the digitalization of fraud. For example, a singer, Ogbogu Okonji, in his song "Alusi Ego", meaning the god(dess) of money, personified Fred Ajedua (an alleged 419-fraud kingpin in the 1990s) as follows (translated from Enuani to English): “ . . /Fred-o! who is like Fred-o!/the God of money, who is like Fred-o/ . . /The sun that shines for the masses/who is like Fred-o!/ ... / ...". 


\subsection{The Villagization of the Modern Public Sphere}

Contemporary Nigerian identities could be seen as Janus-faced. For example, irrespective of the primacy of Christianity or other religions in people's lives, most ethnic groups in Nigeria bury their dead according to indigenous spiritual worldviews and rituals (Ellis 2016). While such burial rites are major community events (Ibrahim 2015; Peavy 2016), they are primarily intended to nurture the relationship between the ancestral spirits and the human family (relationship maintenance is one of the most crucial aspects of material welfare) (Peavy 2016). Drawing from Ekeh (1975), Kalu (2002, p. 674) coined the term "the villagization of the modern public sphere" to describe the Janus-faced identity of modern Nigerians. For Kalu (2002, p. 674), most modern Nigerians are "as viruses feeding on the red blood corpuscles of the primal world and spiritual shrines in rural areas". According to Ekeh's (1975) original formulations, modern Nigerians simultaneously live in two opposed yet intersecting public spheres. The first involves influences from cultural beliefs and practices (e.g., burial rites). It is a local sphere made up of strong bonds of kinship located in villages and the birthplaces and shrines therein. The second sphere is that constituted by colonial endeavors such as the national assembly, parliament, federal government, and the national press. The historical, political, and sociocultural context of Nigeria merged these two spheres, which revolve around familial ties and places of origin or nativity.

Within the Nigerian cultural realm, kinship-nurturing is commonplace (Ibrahim 2015). A man may be the most powerful person in the nation politically, but he is socioculturally indebted to his place of origin. The client-patron relationship between people in the villages/towns (gatekeepers of the shrines and sacred sites) and the holders of political power and national resources is reciprocal (Ekeh 1975). This reciprocity can be understood through an African proverb: "the left-hand washes the right-hand, and the right one washes the left one and both become clean". By implication, "people's socioeconomic insecurity necessitates a strong rather than less reliance on ties to family and community" (Ibrahim 2015, p. 316). People's strong reliance on families and communities also helped vitalize "the villagization of the modern public sphere" exemplified in public-fund embezzlements and spiritual shrine consultations (Ekeh 1975). In this way, national resources are funneled down to one's place of origin, for personal purposes-with impunity ${ }^{23}$.

The cultural and symbolic "hand washing" not only helps harness unity, but also blurs the boundary between the meaning of "bribe" and that of "dash" (Ellis 2016; Osoba 1996). While the sociocultural delineation between the two words is not a sharp line, a "dash" is a local term for a gift in a Nigerian context. Contexts are a resource for understanding any social phenomenon (Goffman [1959] 1990; Morris 2018). Since in a Nigerian context a "bribe", from a cultural, social, or political lens, can be a "dash", it would not be a far stretch to maintain that a "bribe" is a "dash" and a "dash" is a "bribe", depending on the givers' intentions as well as the circumstances or life problems they are given to address. While metaphor establishes the basis of people's everyday comprehension of life (Santa Ana 2002), I argue that it diffuses the meaning of dash and bribe in a Nigerian context. This is because of the following reasons: Although "corruption is a symptom and outcome of institutional deficiency" (Dasgupta and Ugur 2011, p. 2), expertise in bribery has hitherto been deemed necessary and sufficient for political candidates and public post applicants in order for them to be successful in Nigeria (Ellis 2016). Given that in a Nigerian context earthly riches are commonly believed to have spiritual etiology, this worldview on earthly riches has consequences. Some spiritualists and "native doctors" are caught up in the web of bribery (Ibrahim 2016b) within the networks of what Andreski (Stanislav [1968] 1996) called kleptocracy (Stanislav [1968] 1996). Kleptocracy can be defined as a system where the "functioning of the organs of authority is determined by the mechanism of supply and demand rather than the law and regulations", and kleptocrats are the principal social actors in

23 The 'impunity' here implies that under some institutional umbrellas, as Lazarus's (2019, p. 1) literary work depicted, "the fraudsters are also in charge of fraud-taskforce". 
kleptocracies (Stanislav [1968] 1996, p. 109; Osoba 1996, p. 378). For example, the expenditure of large amounts of money and spiritual engagements to acquire a political post has by the same token transformed such political positions into market commodities (Joseph 1987; Osoba 1996). In turn, "market commodities" will inevitably be exploited in to repay any "debts" incurred, in addition to furthering profits and mystical exploitations needed to finance subsequent elections or senior civil-service posts. The foregoing remarks shed light on how cyber-spiritualism may have emerged. By the same token, it also suggests that political corruption is commonplace in Nigeria.

Kalu (2002) and Ekeh (1975) explained that shrines are invaluable political mechanisms for mobilizing economic and sociocultural power in the modern sector and contemporary government offices. For example, it is not uncommon for civil servants or politicians to use the public funds in their possession to finance "worthy" causes in their birthplaces and regularly contribute to the treasury of their "kinsmen" (Ellis 2016). The holders of public posts require spiritual, political, and social support from their places of origin, and their "kinsmen" in the villages can then tap into the economic resources available to politicians and/or holders of public posts (Ekeh 1975; Kalu 2002). Equally, as part of their sacerdotal duties, the gatekeepers of shrines render spiritual services to people (their symbolic sons and daughters) in government and civil service. Reciprocally, the spiritualists gain access to the immense wealth available to the holders of public offices such as those of politicians. Arguably, in Nigeria, as Ellis (2016, p. 195) noted, traditional shrines and churches can be conceptualized as "lubricants of political, civil, and commercial relationships". In this way, meanings of the spirit world as the true source of wealth are continuously produced and reproduced through interactional processes between holders of public posts and chief priests in villages/towns (Blumer 1969a; Carter and Fuller 2016). The above discussion illuminates how and to what extent the relationship between the spiritualists and the holders of public offices in Nigeria forms a critical dynamic in the construction and negotiation of identity and belonging. It also illuminates Kalu's (2002) idea that modern Nigerians could be viewed as "feeding on the red blood corpuscles of the primal world and spiritual shrines in rural areas", as mentioned.

The symbolic meaning of this idea not only reinforces the notion that the spirit world is the true source of material wealth, but also underscores that material wealth embodies not only a mechanical reflection but the imputed sentiments as well. For (Cooley 1992, [1909] 1998), the thing that moves us to our pride or 'shame is not the mere mechanical reflection of ourselves, but an imputed sentiment, and the imagined effect of this reflection upon another's mind-our people'. Arguably, most Nigerians perceive the spirit world (shrines) in their places of origin and their "kinsmen" (keepers of the shrines) as a vital source of legitimacy, a meaningful life, and symbolic sources of their wealth. Similarly, shrine keepers and "kinsmen" see their sons/daughters in public offices as symbols of pride, prestige, and ultimately, sources of wealth (Ekeh 1975). "Ancestral faces saw us, And said: They have not changed!" (Brew 1975, p. 43). Some core aspects of culture are transmitted from generation to generation (Ibrahim 2015; Smalls 2015), and as Brew's (1975) poem depicted above, people are reflections of their ancestral faces. With the aim of tapping spiritual recourses for wealth acquisition, most individuals, families, and villages, regardless of their proclamations of Christianity or other dominant religiosities, have shrines within their residential areas and beyond-gateways to communicate with their ancestors, such as during burial or festive ceremonies. I challenge the simplistic rendering of cyber-spiritualism and indigenous epistemologies in Nigeria as distinctly separate entities with easily defined boundaries, because the polarization of the real world and the virtual world obstructs the understanding of licit cyber-behavior and cybercrime.

\section{Summary}

First, to recapitulate, the use of spiritual powers for financial success is in itself not exclusive to yahoo-yahoo enterprises, but represents a reflection of the broader Nigerian society that created it. By implication, cyber-spiritualism may not be an alien in the body of Nigerian society. Indeed, concerning the licit and illicit tapping of spiritual resources for wealth acquisition, "the line dividing good and evil 
cuts through the heart of every human being", ${ }^{24}$ and this line is thin. Spirituality in the virtual world is an extension of cultural nuances in society, and the tapping of spiritual resources for wealth acquisition is no less critical to cyber criminality than it is to claimed law-abiding citizenship. Yet, claim-makers Tade (2013) and Melvin and Ayotunde (2010) demonized Yahoo-Boys, as in Best's (2008, p. 14) words "a social problem", simply for their involvement in the occult economy in the virtual world. I argue that the relationship between its users, whether cybercriminals or law-abiding citizens, is far more complicated than hitherto portrayed in prevailing scholarship. I also argue that the significance of the spirit world and its connections to the acquisition of wealth online are reflections of well-established indigenous spiritual worldviews in Nigerian society.

The significance of the dual meaning of cyber-spiritualism necessitates a more critical examination of cultural boundaries between law-abiding Nigerians and Yahoo-Boys. If we conceive cyber-spiritualism as a singularity (as having only one dimension), the problem is that we would be led to conclude that cyber-mysticism is an inherently negative phenomenon. This current endeavour argues that cyber-spiritualism embodies dual meanings (the good and the bad) depending on subscribers' intentionality as well as the circumstances and life problems they address. It reinforces the notion that the centrality of the spirit world as a real source of wealth is no less significant to the ethos of law-abiding citizens of Nigerian society than to that of the Yahoo-Boys. This notion, in particular, suggests problems with the prevailing definition of cyber-spiritualism. The "good" and the "bad" components of cyber-spiritualism have previously been taken for granted as only a negative phenomenon, whereas the dual meaning of cyber-spiritualism has implications. Cyber-spiritualism may not in itself "batter the image of Nigeria", as Tade (2013, p. 702) argued. The identification of cyber-spiritualism in cybercrime scholarship simply reinforces the view that spiritual welfare is analogous to material welfare in Nigerian society (Ekeh 1975; Kalu 2002). It is reasonable then to concede that "economic benefits and wealth generation are the primary motives for cybercrime in a Nigerian context" (Ibrahim 2016a, p. 51). Indeed, Yahoo-Boys' deployment of magical and spiritual powers to cast spells on victims in the virtual world is reflective of the connections between the spirit world and the acquisition of wealth in Nigerian society.

\section{Conclusions}

To understand cyber-spiritualism, I have examined the past that created it and found that contemporary manifestations of spirituality in cyberspace (life-online) are a reflection of local epistemologies and worldviews in society (life-offline). In particular, I explored the occult economy in a variety of different manifestations (TASS, Olokun deity, the Gospel of Prosperity, and the villagization of the modern public sphere) in order to demonstrate the intersectionality of the spirit world and the acquisition of wealth, which goes back a long way in Nigerian society. I have proposed that the spiritual world is the base of Nigerian society, upon which the superstructure comprised of all aspects of life, especially wealth, sits. Theoretically, this viewpoint that the spirit world is the base of society, indeed, is an inversion of Orthodox Marxist's theory of economic determinism.

Additionally, I have pointed out that the existing definition of cyber-spiritualism is a recipe for confusion, as it acknowledges only one dimension, and then negativizes it. I have redefined cyber-spiritualism and proposed that it has dual meanings (the good and the bad), like the concept of TASS. Consequently, I have challenged the simplistic rendering of cyber-spiritualism and indigenous epistemologies in Nigeria as distinctly separate entities with easily defined boundaries. In devil advocating the righteousness of claimed law-abiding citizens, I highlighted that the seeming distinctions between them and cybercriminals are blurred with regards to the use of mystical powers to increase material wealth. Where is the money? 'Wealth' is rooted in the spirit world. The centrality of the spirit world in wealth acquisition in the physical realm in Nigeria is reflected in the Yahoo-Boys' modus

24 A famous quote from the Russian scholar Aleksandr Solzhenitsyn. 
operandi in cyberspace. Thus, I have demonstrated that the discrepancies between its users (whether Yahoo-Boys or claimed law-abiding citizens) are far from straightforward. In this context, economic actions are always and inevitably sociocultural actions. They should be interpreted and judged as such. By exploring the moral foundations of economic action (licit/illicit), I have argued that it is misplaced to see Yahoo-Boys' exploitations of spiritual powers in cyberspace as signifying "new danger" and an ever-increasing outrage in Nigerian society. Yahoo-Boys' exploitation of spiritual/magical powers in the virtual world not only aligns with local epistemologies and worldviews on wealth and prosperity, but also highlights that cybercrime in a Nigerian context is rooted in socioeconomics, whose success (like that of licit professions) requires spiritual blessings.

Finally, examining the spiritually embedded economy in all of its complexities would be undermined if tethered to one or two disciplinary contexts and traditions. In this article, I therefore attempted to stimulate an interdisciplinary dialogue between sociology, religious studies, anthropology, and cultural criminology. Analyzing digital spiritualization and contextualizing it within frameworks of traditional and Pentecostal concepts of prosperity and kinship-which may (or may not) develop into practices of political corruption and criminality-is a highly appropriate topic that is underrepresented in research on the intersectionality of religion and economic actions in Africa (or anywhere, for that matter). Contextual and cultural realities on the ground should inform policymaking for information technologies in West Africa, including Nigeria.

The intersectionality of the spirit world and the acquisition of wealth (illicit or licit) are connected with local epistemologies and worldviews, and their contemporaneity has social security benefits through the concept of escapelessness. On a policy level, if digital-age West Africans believe that the spirit world is the true source of wealth and that no offender escapes the punishment of their ancestral spirits and gods (escapelessness), these beliefs have direct policy implications for socioeconomic, cybersecurity, and religious issues in West Africa and elsewhere. In dealing with the historical and foundational issues of socioeconomics and wealth generation, I underscored that life-online is a mere extension of life-offline. A policy conclusion from this article, therefore, is that the above insights from this research could deepen our understanding of the ways local epistemologies and worldviews on wealth acquisition give rise to contemporary manifestations of spirituality in the virtual world. Also, insights from this research could deepen our understanding of the spiritual dynamics of the relationship between Yahoo-Boys and their victims all over the world. A better understanding of this type of online fraud can be achieved when we unconditionally value, sponsor, and share all insights from across the global South and the global North, as Lazarus (2018) and Cross (2018) have suggested. I, therefore, urge cyber-fraud researchers to look beyond normal "scientific evidence" and consider the traces of "spiritual manipulations of victims" for material gains that are all too often ignored in "normal social science".

Funding: This research received no external funding.

Acknowledgments: I thank Afe Adogame, Tim Hall, and the anonymous referees for their insightful suggestions. I also thank Stephen Wyatt and Jeffrey Marck for their gratis efforts in proofreading portions of this article.

Conflicts of Interest: The author declares no conflict of interest.

\section{References}

Adebayo, Anthony Abayomi. 2013. Youths' unemployment and crime in Nigeria: A nexus and implications for national development. International Journal of Sociology and Anthropology 5: 350. [CrossRef]

Adogame, Afe. 2010. How God became a Nigerian: Religious impulse and the unfolding of a nation. Journal of Contemporary African Studies 28: 479-98. [CrossRef]

Adogame, Afeosemime, Ezra Chitando, and Bolaji Bateye. 2012. African Traditions in the Study of Religion in Africa: Emerging Trends, Indigenous Spirituality and the Interface with Other World Religions. London: Ashgate Publishing, Ltd. 
Aghedo, Iro. 2015. Sowing peace, reaping violence: Understanding the resurgence of kidnapping in post-amnesty Niger Delta, Nigeria. Insight on Africa 7: 137-53. [CrossRef]

Agozino, Biko. 2017. Critical Perspectives on Deviance and Social Control in Rural Africa. African Journal of Criminology and Justice Studies: AJCJS 10: I.

Ajirola, Felix Oludare. 2015. Globalisation and the Nigerian Youths. Available online: https: / /www.researchgate.net/publication/281069059_GLOBALIZATION_AFRICAN_CULTURE_AND_ JUVENILE_DELINQUENCY (accessed on 26 September 2018).

Akanle, Olayinka, and Gbenga S. Adejare. 2018. Contextualizing Pentecostal Gatherings in Southwestern Nigeria: Social Drivers and Significance. In Religion in Context. Baden-Baden: Nomos Verlagsgesellschaft, pp. 145-58.

Akanle, Olayinka, J. O. Adesina, and E. P. Akarah. 2016. Towards human dignity and the internet: The cybercrime (yahoo yahoo) phenomenon in Nigeria. African Journal of Science, Technology, Innovation and Development 8: 213-20. [CrossRef]

Amadi, Richard Nlemanya, Efetobor O. Elijah, and Grace Nnennaya Nwaubeta. 2017. Rethinking the etiology of names as communication channels in Nigeria. International Journal of Research and Development Studies 8: 1-15.

Amanze, James N. 2013. The role of prophecy in the growth and expansion of the Synagogue Church of All Na ons. Scriptura 112: 1-14. [CrossRef]

Amponsah, Benjamin, Charity Akotia, and Akinsola Olowu. 2006. Ghana. In Families across Cultures: A 30-Nation Psychological Study. Edited by James Georgas, John W. Berry, Fons J. van de Vijver, Çigdem Kagitçibasi and Ype H. Poortinga. Cambridge: Cambridge University Press.

Aransiola, Joshua Oyeniyi, and Suraj Olalekan Asindemade. 2011. Understanding cybercrime perpetrators and the strategies they employ in Nigeria. Cyberpsychology, Behavior, and Social Networking 14: 759-63. [CrossRef] [PubMed]

Assimeng, Max. 1986. Social Structure of Ghana. Accra: Ghana Universities Press.

Becker, Howard S. 1997. Outsiders: Studies in Sociology of Deviance. New York: Simon and Schuster Ltd. First published 1967.

Beirne, Piers. 1983. Cultural relativism and comparative criminology. Crime, Law and Social Change 7: 371-91. [CrossRef]

Best, Joel. 2008. Social Problems. New York: WW Norton.

Bever, Edward, and Randall Styers. 2018. Magic in the Modern World. Pennsylvania: Pennsylvania State University Press.

Blumer, Herbert. 1969a. Symbolic Interactionism: Perspective and Method. Eaglewood Cliffs: Prentice Hall.

Blumer, Herbert. 1969b. The Methodological Position of Symbolic Interactionism', in Symbolic Interaction. Eaglewood Cliffs: Prentice-Hall.

Brew, Kwesi. 1975. Ancestral Faces. In Poems of Black Africa. Edited by Wole Soyinka. London: Heinemann Educational Books Ltd., p. 43.

Button, Mark, and Cassandra Cross. 2017. Cyber Frauds, Scams and Their Victims. New York: Taylor \& Francis.

Carter, Michael J., and Celene Fuller. 2016. Symbols, meaning, and action: The past, present, and future of symbolic interactionism. Current Sociology 64: 931-61. [CrossRef]

Clark, John Pepper. 1975. Olokun. In Poems of Black Africa. Edited by Wole Soyinka. London: Heinemann Educational Books Ltd., pp. 43-44.

Cohen, Stanley. 1988. Against Criminology. New Brunswick: Transaction.

Comaroff, Jean, and John L. Comaroff. 1999. Occult economies and the violence of abstraction: Notes from the South African postcolony. American Ethnologist 26: 279-303. [CrossRef]

Cooley, Charles Horton. 1998. On Self and Social Organisation. Chicago: The University of Chicago Press. First published 1909.

Cooley, Charles Horton. 1992. Human Nature and the Social Order. London: Transaction Publishers.

Cross, Cassandra. 2018. Marginalized voices: The absence of Nigerian scholars in global examinations of online fraud. In The Palgrave Handbook of Criminology and the Global South. Cham: Palgrave Macmillan, pp. 261-80.

Csordas, Thomas J., ed. 2009. Introduction: Modalies of transnational transcendence. In Transnational Transcendence: Essays on Religion and Globalisation. Berkeley: University of California Press, pp. 1-29.

Dasgupta, Nandini, and Mehmet Ugur. 2011. Evidence on the Economic Growth Impacts of Corruption in Low-Income Countries and Beyond: A Systematic Review. London: EPPI-Centre, Social Science Research Unit, Institute of Education, University of London. 
Dobovšek, Bojan, Igor Lamberger, and Boštjan Slak. 2013. Advance fee frauds messages-non-declining trend. Journal of Money Laundering Control 16: 209-30. [CrossRef]

Droz, Yvan, and Yonatan Gez. 2015. A god trap: Seed planting, gift logic, and the prosperity gospel. In Pastures of Plenty: Tracing Religio-Scapes of Prosperity Gospel in Africa and Beyond. Edited by Andreas Heuser. Frankfurt: Lang, pp. 295-307.

Ekeh, Peter P. 1975. Colonialism and the two publics in Africa: A theoretical statement. Comparative Studies in Society and History 17: 91-112. [CrossRef]

Ellis, Stephen. 2016. This Present Darkness: A History of Nigerian Organized Crime. Oxford: Oxford University Press.

Falola, Toyin. 1995. Money and Informal Credit Institutions in Colonial Western Nigeria. In Money Matters: Instability, Values and Social Payment in the Modern History of West African Communities. Edited by Jane Guyer. London: James Currey, pp. 162-87.

Fowles, Jib. 1977. The problem of values in futures research. Futures 9: 303-14. [CrossRef]

Gabe, Jonathan, and Michael Bury. 1988. Tranquillisers as a social problem. The Sociological Review 36: 320-52. [CrossRef]

Goffman, Erving. 1990. The Presentation of Self in Everyday Life. New York: Doubleday. First published 1959.

Goutam, Rajesh Kumar, and Deepak Kumar Verma. 2015. Top Five Cyber Frauds. International Journal of Computer Applications 119: 23-25. [CrossRef]

Guyer, Jane. 2004. Marginal Gains: Monetary Transactions in Atlantic Africa. Chicago: Chicago University Press.

Heuser, Andreas. 2016. Charting African Prosperity Gospel economies. HTS Theological Studies 72: 1-9. [CrossRef]

Ibrahim, Suleman. 2015. A Binary Model of Broken Home: Parental Death-Divorce Hypothesis of Male Juvenile Delinquency in Nigeria and Ghana. In Contemporary Perspectives in Family Research. Edited by Sheila Royo Maxwell and Sampson Lee Blair. New York: Emerald Group Publishing Limited, vol. 9, pp. 311-40.

Ibrahim, Suleman. 2016a. Social and contextual taxonomy of cybercrime: Socioeconomic theory of Nigerian cybercriminals. International Journal of Law, Crime and Justice 47: 44-57. [CrossRef]

Ibrahim, Suleman. 2016b. Causes of socioeconomic cybercrime in Nigeria. Paper presented at IEEE International Conference on Cybercrime and Computer Forensic (ICCCF), Vancouver, BC, Canada, June 12-14; pp. 1-9.

Igbinovia, Patrick Edobor. 1988. Ritual murders in Nigeria. International Journal of Offender Therapy and Comparative Criminology 32: 37-43. [CrossRef]

Igwe, Chidi Nnamdi. 2007. Taking Back Nigeria from 419: What to Do about the Worldwide E-mail Scam-Advance-Fee Fraud. Toronto: iUniverse.

Information Nigeria. 2017. Girls Run Mad. Available online: http:/ /www.informationng.com/2017/07/girls-runmad-become-useless-use-yahoo-plus-yahoo-boys-confesses.html (accessed on 20 January 2018).

Jaishankar, Karuppannan. 2007. Cyber criminology: Evolving a novel discipline with a new journal. International Journal of Cyber Criminology 1: 1-6.

Jaishankar, Karuppannan, ed. 2011. Introduction: Expanding Cyber Criminology with an Avant-Garde Anthology. In Cyber Criminology: Exploring Internet Crimes and Criminal Behavior. Boca Raton: CRC Press, pp. xxvii-xxxv.

Jansen, Jan. 2011. Framing divination: A Mande divination expert and the occult economy. Africa 79: 110-27. [CrossRef]

Joseph, Richard A. 1987. Democracy and Prebendal Politics in Nigeria: The Rise and Fall of the Second Republic. Cambridge: Cambridge University Press.

Kalu, O. U. 1977. Missionaries, Colonial Government and Secret Societies in South-Eastern Igboland, 1920-1950. Journal of the Historical Society of Nigeria 9: 75-90.

Kalu, Ogbu U. 2002. The Religious Dimension of the Legitimacy Crisis, 1993-1998. In Nigeria in the Twentieth Century. Edited by Toyin Falola. Durham: Carolina Academics Press, pp. 667-85.

Kangwa, Jonathan. 2016. The role of the theology of retribution in the growth of Pentecostal-Charismatic churches in Africa. Verbum et Ecclesia 37: 1-9. [CrossRef]

Kirillova, Elena Anatolyevna, Rashad Afatovich Kurbanov, Natalia Viktorovna Svechnikova, Teymur El'darovich Zul'fugarzade, and Sergey Sergeevich Zenin. 2017. Problems of Fighting Crimes on the Internet. Journal of Advanced Research in Law and Economics 8: 849-56.

Lausanne Theology Working Group. 2010. A Statement on the Prosperity Gospel. Available online: https: / / www.lausanne.org/content/a-statement-on-the-prosperity-gospel (accessed on 7 July 2018).

Lazarus, Suleman. 2018. Birds of a Feather Flock Together: The Nigerian Cyber Fraudsters (Yahoo Boys) and Hip Hop Artists. Criminology, Criminal Justice, Law \& Society 19: 63-80. 
Lazarus, Suleman. 2019. Betrayals in Academia and a Black Demon from Ephesus. Wisdom in Education 9: 1-2.

Lazarus, Suleman, and Geoffrey Uzoma Okolorie. 2019. The Bifurcation of Nigerian Cybercriminals: Narratives of the Economic and Financial Crimes Commission (EFCC) Agents. Available online: https:/ /ssrn.com/ abstract=3331970 (accessed on 8 February 2019).

Lazarus, Suleman Ibrahim, Michael Rush, Edward T. Dibiana, and Claire P. Monks. 2017. Gendered penalties of divorce on remarriage in Nigeria: A qualitative study. Journal of Comparative Family Studies 48: 351-66. [CrossRef]

Longo, Mariano. 2015. Fiction and Social Reality: Literature and Narrative as Sociological Resources. Surrey: Ashgate Publishing Limited.

Magezi, Vhumani, and Christopher Magezi. 2017. A pastoral evaluation and responses to the challenge of spiritual insecurity in African pastoral ministry and Christianity. Verbum et Ecclesia 38: 1-13. [CrossRef]

Marx, Karl, and Friedrich Engel. 1967. The Communist Manifesto. London: Penguin Classics. First published in 1848.

Matza, David, and Gresham M. Sykes. 1961. Juvenile Delinquency and Subterranean Values. American Sociological Review 26: 712-19. [CrossRef]

Mauss, Marcel. 1925. The Gift. London: Routledge.

McGerty, Lisa Jane. 2000. "Nobody Lives Only in Cyberspace": Gendered Subjectivities and Domestic Use of the Internet. Cyberpsychology, Behavior, and Social Networking 3: 895-99. [CrossRef]

Melvin, Agunbiade Ojo, and Titilayo Ayotunde. 2010. Spirituality in Cybercrime (Yahoo-Yahoo) Activities among Youths in South West Nigeria. In Youth Culture and Net Culture: Online Social Practices: Online Social Practices. Hershey: IGI Global, pp. 357-76.

Morahan-Martin, Janet. 2000. Women and the Internet: Promise and Perils. Cyberpsychology, Behavior, and Social Networking 3: 683-91. [CrossRef]

Morris, Craig. 2018. 'You can't stand on a corner and talk about it ... ': Medicinal cannabis use, impression management and the analytical status of interviews. Methodological Innovations 11: 1-12. [CrossRef]

Nkoh, Martius. 1963. The Sorrow of Man. Enugu: Okolue Books.

Ogwezzy, Michael Chukwujindu. 2012. Cyber crime and the proliferation of yahoo addicts in Nigeria. International Journal of Juridical Sciences 1: 86-102.

Okri, Ben. 1991. The Famished Road. London: Jonathan Cape.

Osoba, Segun O. 1996. Corruption in Nigeria: Historical perspectives. Review of African Political Economy 23: 371-86. [CrossRef]

Peavy, Daryl. 2016. The Benin Monarchy, Olokun and Iha Ominigbọn. Journal of Benin and Edo Studies 1: 95-127.

Peek, Philip M. 1991. African Divination Systems: Ways of Knowing. Washington, DC: Georgetown University Press.

Peek, Philip M. 2016. 'Twinning' and 'Perfect knowledge' in African Systems of Divination. In Divination: Perspectives for a New Millennium. Edited by Curry Pactrick. London: Routledge.

Powell, Anastasia, Gregory Stratton, and Robin Cameron. 2017. Crime and Justice in Digital Society: Towards a ‘Digital Criminology'? International Journal for Crime, Justice and Social Democracy 6: 17-33.

Powell, Anastasia, Gregory Stratton, and Robin Cameron. 2018. Digital Criminology: Crime and Justice in Digital Society. New York: Routledge.

Reiner, Robert. 2016. Crime, the Mystery of the Common-Sense Concept. New York: John Wiley \& Sons.

Rich, Timothy. 2018. You can trust me: A multimethod analysis of the Nigerian email scam. Security Journal 31: 1-18. [CrossRef]

Rock, Paul. 2005. Chronocentricism and British Criminology. The British Journal of Sociology 56: 473-91. [CrossRef] [PubMed]

Rosen, Norma. 1989. Chalk Iconography in Olokun Worship. African Arts 22: 44-53. [CrossRef]

Rush, Michael, and Suleman Ibrahim Lazarus. 2018. 'Troubling' Chastisement: A Comparative Historical Analysis of Child Punishment in Ghana and Ireland. Sociological Research Online 23: 177-96. [CrossRef]

Santa Ana, Otto. 2002. Brown Tide Rising: Metaphors of Latinos in Contemporary American Public Discourse. Austin: University of Texas Press.

Shankland. 1933. Intelligent report on the Aro by T. M. Shankland. CSO 26/29017. Ibadan: National Archives Ibadan, p. 13.

Smalls, James. 2015. The Science of Vodun, Vodoo: Professor James Smalls. [Online Video]. Available online: https: / / www.youtube.com/watch?v=6YkEPelFOKE (accessed on 5 December 2017). 
Sogolo, Godwin S. 1991. The concept of cause in African thought. In Philosophy from Africa: A Text with Readings. Edited by Pieter Hendrik Cotzee and Abraham Pieter Jacob Roux. Oxford: Oxford University Press, pp. 177-85.

Stanislav, Andreski. 1996. The African Predicament: A Study in the Pathology of Modernisation. London: Michael Joseph. First published 1968.

Steinmüller, Hans. 2011. The moving boundaries of social heat: Gambling in rural China. Journal of the Royal Anthropological Institute 17: 263-80. [CrossRef]

Tade, Oludayo. 2013. A spiritual dimension to cybercrime in Nigeria: The 'yahoo plus' phenomenon. Human Affairs 23: 689-705. [CrossRef]

Tankebe, Justice. 2008. Colonialism, legitimation, and policing in Ghana. International Journal of Law, Crime and Justice 36: 67-84. [CrossRef]

Thomas, William Isaac, and Dorothy Swaine Thomas. 1928. The Child in America: Behaviour Problems and Programmes. New York: Alfred Knopf.

Trend Micro and INTERPOL. 2017. Cybercrime in West Africa: Poised for an Underground Market. Available online: https:/ / documents.trendmicro.com/assets/wp/wp-cybercrime-in-west-africa.pdf (accessed on 7 July 2016).

Tyler, Tom. 1990. Why People Obey the Law. New Haven: Yale University Press.

Ujumadu, Vincent. 2015. Okija Shrine: No Longer a Bee-Hive of Activities for Politicians. Available online: https:/ / www.vanguardngr.com/2015/08/okija-shrine-no-longer-a-bee-hive-of-activities-for-politicians / (accessed on 20 November 2016).

US Consulate. 1949. Records of the US Consulate, National Archives and Records Administration, Washington DC (NARA): Record Group 84, Classified General Records of the US Consulate and Embassy, Lagos, Nigeria, 1940-63, Box 1: C. Porter Kuykendall, Consul-General, to Secretary of State, May 16; Washington, DC: NARA.

Washington, Teresa N. 2012. Mules and Men and Messiahs: Continuity in Yoruba Divination Verses and African American Folktales. Journal of American Folklore 125: 263-85. [CrossRef]

Weber, Max. 1992. Economy and Society: An Outline of Interpretative Sociology. Berkeley: California University Press. First published 1946.

Whitty, Monica, Matthew Edwards, Michael Levi, Claudia Peersman, Awais Rashid, Angela Sasse, Tom Sorell, and Gianluca Stringhini. 2017. Ethical and Social Challenges with developing Automated Methods to Detect and Warn potential victims of Mass-marketing Fraud (MMF). Paper presented at 26th International Conference on World Wide Web Companion, Perth, Australian, April 3-7; pp. 1311-14. 